How to cite this article:

Azrae, A. N. (2020). Reassessing the roles of the Yang di-Pertuan Agong and the Rulers in the making of international treaties. UUM Journal of Legal Studies, 11(2), 117-152. https://doi.org/10.32890/uumjls.11.2.2020.8006

\title{
REASSESSING THE ROLES OF THE YANG DI-PERTUAN AGONG AND THE RULERS IN THE MAKING OF INTERNATIONAL TREATIES
}

\author{
Ahmad Nasyran Azrae \\ School of Law, College of Law, \\ Government and International Studies \\ Universiti Utara Malaysia, Kedah, Malaysia \\ nasyran@uum.edu.my
}

Received: 9/1/2020 Revised: 5/5/2020 Accepted: 10/6/2020 Published: 31/7/2020

\begin{abstract}
Malaysia continuously negotiates, signs and ratifies international treaties tofostercloserrelationships with its counterparts. The Federal Constitution of Malaysia provides no direct provision in granting treaty-making capacity to a specific person(s) or institution(s). However, it may be deduced from the available provisions that such power is exercisable by the executive arm of the Federal Government. By definition, the executive includes the Yang di-Pertuan Agong, who is elected among the Malay Rulers by the Conference of Rulers. This paper reassesses the roles and functions of the Yang di-Pertuan Agong and the Rulers in the making of international treaties. The study was carried out using library based research method which assessed the provisions of the Federal Constitution, local case(s) and international conventions, in particular the Vienna Convention on the Law of Treaties 1969. The paper delved into the available legal documents to explain the functions of the Yang di-Pertuan Agong and the Rulers under the Federal Constitution and accordingly reassessed the legal positions of the Yang di-Pertuan Agong and the
\end{abstract}


Rulers in the making of international treaties. The findings of this paper showed that in practice, the Yang di-Pertuan Agong and the Rulers have no executive powers to conclude and sign international treaties. Nonetheless, the Federal Constitution does confer certain limited powers on the Yang di-Pertuan Agong and the Rulers that may indirectly influence the making of international treaties where their roles are normally consultative in nature.

Keywords: Treaty-making, executive authority, federal constitution, international law.

\section{INTRODUCTION}

Malaysia pursues international cooperation with members of the international communities, which covers both States and international organizations. Malaysia became a member of the United Nations (UN), an international arena in September 1957, less than one month after achieving independence. Besides the UN, Malaysia also participated in several other key organizations, including the World Trade Organization (WTO) and the Organisation of Islamic Cooperation (OIC). At the regional level, Malaysia's commitment towards fostering international cooperation is mainly realised through its participation in the Association of Southeast Asian Nations (ASEAN) since its inception in 1967. In addition, Malaysia also establishes bilateral ties with a number of country partners such as Pakistan, New Zealand, India, Chile, Australia and Turkey. This cooperation is predominantly effected through the conclusion of international treaties that spelt out the rights and duties governing the relationship between the State-parties.

In the past few years, the Government had made a number of controversial decisions with regard to participating in international treaties. For instance, on 4 April 2016, the government had joined 11 other Pacific nations in signing the now discontinued TransPacific Partnership Agreement ('TPPA'). ${ }^{1}$ The TPPA was signed by

\footnotetext{
Howard, R. (2016, February 4). Pacific rim trade deal signed, but years of negotiations still to come. Reuters. Retrieved from https:/www. reuters.com/article/us-trade-tpp/trans-pacific-partnership-trade-dealsigned-but-years-of-negotiations-still-to-come-idUSKCN0VD08S;
} 
the then Minister of International Trade and Industry despite strong opposition from different factions within the country. The TPPA perceived as harmful to the national, economic and bumiputera interests. ${ }^{2}$ Following this was the unpopular announcement from the ruling Pakatan Harapan ('PH') government to accede to the International Convention on the Elimination of All Forms of Racial Discrimination ('ICERD'). ${ }^{3}$ The majority of the Malays rejected ICERD as it jeopardized the privileges of the Malay Rulers, the Malays, the bumiputeras and the religion of Islam as guaranteed in the Federal Constitution. ${ }^{4}$

Conceivably, the most significant turn of events came in March 2019 when the PH government officially acceded to the Rome Statute of the International Criminal Court 1998 ('Rome Statute'). ${ }^{5}$ The decision

Malaysia inks landmark TPPA. (2016, February 5). The Star Online. Retrieved from https://www.thestar.com.my/news/nation/2016/02/05/ malaysia-inks-landmark-tppa-it-joins-11-other-nations-in-signingpact.

2 Lim, I. (2017, January 31). US' withdrawal no cause for celebration with Malaysia's anti-TPPA groups. MalayMail. Retrieved from https:// www.malaymail.com/news/malaysia/2017/01/31/us-withdrawalno-cause-for-celebration-with-malaysias-anti-tppa-groups/1303305; Bantah TPPA. (2016, January 27). Bantah TPPA's response to Mustapa's speech. MalaysiaKini. Retrieved from https://www.malaysiakini.com/ letters/328359.

3 Minister: govt to ratify convention on racial discrimination, five other treaties in q1 2019. (2018, October 25). Malaysia Today. Retreived from https://www.malaysia-today.net/2018/10/25/minister-govt-toratify-convention-on-racial-discrimination-five-other-treaties-in-q12019/.

4 Govt not ratifying ICERD. (2018, November 24). The Star Online. Retreived from https://www.thestar.com.my/news/nation/2018/11/24/ govt-not-ratifying-icerd-we-will-continue-to-defend-federalconstitution-says-pms-office; Malaysia govt says it won't ratify UN rights treaty after facing anger from malays and muslims. (2018, November 23). The Straits Times. Retrieved from https://www. straitstimes.com/asia/se-asia/malaysia-govt-says-wont-ratify-rightstreaty-after-facing-anger-from-malays-and-muslims.

5 Ministry of Foreign Affairs. (2019, March 4). Malaysia accedes to the Rome statute of the international criminal court [Press release]. Retrieved from http://www.kln.gov.my/web/guest/home2/-/asset_publisher/satu tab/content/press-release-malaysia-accedes-to-the-rome-statute-of-theinternational-criminal-court?inheritRedirect=false. 
had caught the interests of many, including from the royalty. The signing of the Rome Statute brought condemnation based on few grounds. First, the Rome Statute perceived as encroaching on the position of the monarch and the immunity of the Yang di-Pertuan Agong ('YDPA'). Second, the Government became a subject of criticism for acting against the Federal Constitution when they acceded to the Rome Statute without consulting the Conference of Rulers (COR), whose interests could be jeopardised under the treaty. ${ }^{6}$ Besides, the Foreign Minister had to brief the YDPA on the latest status and development following the government's accession to the Rome Statute. ${ }^{7}$ Relentless pressure 'forced' the government to withdraw from the Rome Statute in April 2019, slightly one month after acceding to the treaty. In announcing the government's decision, Prime Minister Mahathir cited that withdrawal from the Rome Statute was to avoid 'political confusion' created by certain groups of people with personal interests. ${ }^{8}$

The events following the accession to the Rome Statute raised some noteworthy points that require appropriate legal assessment. The role of the YDPA and the Rulers, which constitute the COR, in the making of international treaties became the centre of attention. This is supported by the following facts, namely: a letter was presented to the acting YDPA informing His Royal Highness on the Cabinet's decision to accede to the Rome Statute; the Minister of Foreign Affairs was called to brief the YDPA on the status of Malaysia's

6 Malaysia withdraws from the Rome statute. (2019, April 5). The Star Online. Retrieved from https://www.thestar.com.my/news/ nation/2019/04/05/malaysia-withdraws-from-the-rome-statute; Malaysia withdraws from the Rome statute of the international criminal court. (2019, April 5). The Straits Times. Retreived from https://www. straitstimes.com/asia/se-asia/malaysia-withdraws-from-the-romestatute.

7 Prime Minister's Office of Malaysia. (2019, March 13). Kenyataan akhbar berhubung menteri luar negeri menghadap KDYMM Seri Paduka Baginda Yang di-Pertuan Agong [Press release]. Retrieved from https://www.pmo.gov.my/2019/03/kenyataan-akhbar-berhubungmenteri-luar-negeri-menghadap-kebawah-duli-yang-maha-mulia-seripaduka-baginda-yang-di-pertuan-agong-kln/.

8 Malaysia withdraws from the Rome statute. (2019, April 5); Malaysia withdraws from the Rome statute of the international criminal court. (2019, April 5). 
participation in the Rome Statute; and the allegation that the COR was not consulted prior to the signing of the instrument of accession.

Accordingly, this paper seeks to reassess the position and the role of the YDPA and the Rulers in the making of international treaties. The study was carried out using library based research method which assessed the provisions from the Federal Constitution, local case(s) and the Vienna Convention on the Law of Treaties 1969 ('Vienna Convention 1969'), being the main source of international law regulating the law of treaties.

The discussion is divided into three main parts. The first part defines the meaning and application of treaties in the context of international law. The second part explains the position of the institutions of the YDPA and the Rulers under the Federal Constitution. The third part reassesses the role of the YDPA and the Rulers in the making of international treaties with reference to the Vienna Convention 1969, the Federal Constitution and supported by decided case(s).

\section{DEFINITION OF TREATIES}

Generally, 'treaty' refers to a legally binding agreement concluded by international personalities, namely States and inter-governmental organizations recognized as having treaty-making capacities. Oppenheim (1955) described treaties as "agreements, of a contractual character, between States, or organizations of States, creating legal rights and obligations between the parties." According to Schwarzenberger (1949), a treaty means "a consensual engagement which subjects of international law have undertaken towards one another, with the intent to create legal obligations under international law." 10

The legal meaning of treaty can be found in Art. 2(1)(a), Vienna Convention 1969, which defines treaty as "an international agreement concluded between States in written form and governed

9 Oppenheim, L. (1955). International Law: A Treatise, vol. 1, edited by H. Lauterpacht. New York: Congmans, Green.

10 Schwarzenberger, G. (1949). International law as applied by international courts and tribunals, vol. 1. Stevens and Sons. 
by international law, whether embodied in a single instrument or in two or more related instruments and whatever its particular designation." The international agreement between States referred to above are normally concluded and designated with various names including treaty, convention, charter, covenant, statute, agreement, pact, protocol, accord, exchange of notes, etc.

Treaties are regarded as the most important documents in international law that regulates international relations. This is because a treaty is the only means by which States deliberately establish the law for themselves. The importance of treaty was clarified by Hamid who wrote, "treaty is the most useful instrument through which all kinds of international transactions are concluded." 11 He further clarified the use of treaties by States to regulate international trade, delineate boundaries, resolve conflicts and differences, establish international and regional organizations, etc. ${ }^{12}$ In fact, the multilateral treaties that are participated by a substantial number of State parties are considered as the best medium for imposing binding and precise international rules in various areas of activities.

The essence of treaties as the primary source of international law was underlined in the Statute of the International Court of Justice ('ICJ Statute'). Art. 38(1)(a) which provides that, "[t]he Court, whose function is to decide in accordance with international law such disputes as are submitted to it, shall apply: (a) international conventions, whether general or particular, establishing rules expressly recognized by the contesting States." Treaties as a source of law may be contextualized under two situations. First, treaties that are concluded by a substantial number of States and that stipulate for the general rules of international conduct are called 'law-making treaties' and shall be treated as direct sources of international law. Second, treaties that are concluded between two or only a few States and that deals with a special matter directly affecting the particular States are categorized as 'treaty-contracts'. This type of treaties is similar to contracts concluded at the domestic level and becomes the source of legal transactions for the States. In essence, they still create binding obligations on the parties thereto, and thus constitute particular law for the State-parties.

\footnotetext{
11 Hamid, A. G. @ Khin Maung Sein. (2019). Public international law: A practical approach (4 ${ }^{\text {th }}$ ed.). Singapore: Sweet \& Maxwell.

12 Ibid.
} 
The obligation for observing a treaty is contained in the doctrine of pacta sunt servanda, which means 'agreements must be kept.'13 This rule incorporated in Art. 26, Vienna Convention 1969 that reads "[e]very treaty in force is binding upon the parties to it and must be performed by them in good faith." The rationale behind this obligation is because States have consented to the terms of the treaties and all legal undertakings arising from the same. In other words, the State-parties subscribed to the treaties, which in turn becomes law governing their relationships. Conversely, a treaty will not create obligations on the States that have not consented to the terms of the treaty. ${ }^{14}$

\section{THE INSTITUTIONS OF THE YDPA AND THE RULERS UNDER THE FEDERAL CONSTITUTION}

According to Harding, Malaysia is a unique country, ruled by nine monarchies. ${ }^{15}$ This monarchy system in Malaysia has a long history, going back to the foundations of the Kedah Sultanate in 630, followed by the Malacca Sultanate in $1262 .{ }^{16}$ The modern characterization of the monarchy was defined in the Federal Constitution that covers two institutions, namely the YDPA and the Rulers. The YDPA assumes the office of the Head of State at the federal level, while the Rulers exercise the function of Heads of State at the state level. As Heads of State, the YDPA and the Rulers are normally restricted to perform symbolic and ceremonial functions, although they may, in limited occasions, exercise activist roles. ${ }^{17}$

Generally, the Rulers refer to the nine surviving Malay Sultanates that have continued to exist after Independence and remained

13 Garner, B. A. (Ed. in Chief). (2007). Black's law dictionary (8 $8^{\text {th }}$ Ed.). Minnesota: Thomson West.

14 Art. 34, Vienna Convention 1969.

15 Harding, A. (1996). Law, government \& the constitution in Malaysia. Kuala Lumpur: Malaysian Law Journal Sdn. Bhd.

16 Ghazali, A. Z. Bin. (2019). "Cabaran Institusi Beraja di Malaysia dari Dahulu Hingga Kini” Jabatan Muzium Malaysia, 1-38. Retrieved from http://www.jmm.gov.my/files/Cabaran Institusi Beraja di Malaysia dari Dahulu Hingga Kini_1.pdf.

17 Bari, A. A. (2003). Malaysian constitution: A critical introduction. Kuala Lumpur: The Other Press. 
as such until today. The Rulers assemble in the COR, known as Majlis Raja-raja, which is formally constituted under the Federal Constitution. The COR elects from among the nine Malay Rulers a Ruler to hold the office of the YDPA. The appointment to the office of the YDPA is made on a rotation basis and the elected Ruler holds office for a term of five years. Unlike the office of the Rulers that has survived through history, the office of the YDPA was only set up in 1957 under the Federal Constitution. The following discussion will briefly explain some key provisions that govern the position and roles of the institutions of the YDPA and the Rulers under the Federal Constitution.

\section{The YDPA}

Art. 32(1), Federal Constitution provides that the YDPA is the Supreme Head of the Federation; and he takes precedence over all persons within the country. Clause (3) further explains that the YDPA is elected by the COR from among the nine Malay Rulers for a five-year term. Unless he chooses to resign or is removed from the office by the COR, the YDPA ceases to hold office on ceasing to be a Ruler. ${ }^{18}$ Additionally, the YDPA holds the position as the head of the religion of Islam in the states of Penang, Malacca, Sabah and Sarawak, and the Federal Territories of Kuala Lumpur, Labuan and Putrajaya. ${ }^{19}$ Art. 153, Federal Constitution places a responsibility on the YDPA to safeguard the special position of the Malays and the natives of Sabah and Sarawak and the legitimate interests of other communities.

The YDPA assumes important functions extending to all three State organs-the executive, legislative and judiciary. Art. 39, Federal Constitution states that the YDPA is vested with the executive authority of the Federation, which shall be exercised by him or by the Cabinet or any Minister authorized by the Cabinet. However, in the exercise of his functions, Art 40(1), Federal Constitution requires the YDPA to act in accordance with the advice of the Cabinet or of a Minister acting under the general authority of the Cabinet. Clause (1A) denotes the reference made to "acting in accordance with the

\footnotetext{
18 See further Third Schedule to the Federal Constitution which regulates for the election to the offices of the YDPA and the Deputy YDPA.

19 Art. 3(1) and (5), Federal Constitution.
} 
advice, on advice or after considering advice" as requiring the YDPA to accept and act in accordance with such advice. Nonetheless this rule does not take away the YDPA's power to request any information from the Cabinet in relation to the Federal Government. ${ }^{20}$

The executive functions of the YDPA as outlined in the Federal Constitution include the following:

(i) to appoint a Prime Minister [Art. 40(2)(a)];

(ii) to withhold consent to a request for dissolving the Parliament [Art. 40(2)(b)];

(iii) to request for a meeting of the COR to discuss matters concerning the privileges, position, honour and dignity of the Rulers [Art. 40(2)(c)];

(iv) to hold the position of the Supreme Commander of the armed forces of the Federation [Art. 41];

(v) to grant pardons, reprieves and respites in respect of all offences tried by court-martial and all offences committed in the Federal Territories of Kuala Lumpur, Labuan and Putrajaya [Art. 42(1)];

(vi) to appoint a Jemaah Menteri or Cabinet of Ministers, consisting of a Prime Minister and the Ministers [Art. 43(1) and (2)]; and

(vii) to appoint the Deputy Ministers [Art. 43A(1)].

The legislative authority of the YDPA is provided for under Art. 44, Federal Constitution. The YDPA constitutes one of the three constituents of the Parliament, alongside the House of Senate (Dewan Negara) and the House of Representatives (Dewan Rakyat). The Federal Constitution enumerates several functions of the YDPA affecting the legislature, which includes:

(i) to summon, prorogue or dissolve the Parliament [Art. 55];

(ii) to address the Houses of Parliament [Art. 60];

(iii) to appoint the Clerk to both Houses of Parliament [Art. 65(2)]; and

(iv) to assent to the Bills passed by the Houses of Parliament [Art. $66]$.

Besides exercising the executive and legislative powers, the YDPA also performs several functions relating to the judiciary. Primarily,

20 Art. 40(1), Federal Constitution. 
the YDPA is responsible for appointing judges to hold the main offices of the judiciary. ${ }^{21}$ They are the Chief Justice of the Federal Court, the President of the Court of Appeal, and the Chief Judges of the High Courts. Likewise, the YDPA is responsible for appointing superior court judges to sit in the Federal Court, the Court of Appeal and the High Courts. In appointing the judges referred to above, the YDPA is required to act on the Prime Minister's advice, after consulting the COR. ${ }^{22}$

Additionally, the Federal Constitution empowers the YDPA to appoint persons to hold several key offices within the Federation. These offices or institutions include the Auditor General [Art. 105], the Election Commission [Art. 114(1)]; the Chief of Defence Forces [Art. 137(3)(c)]; members of the Public Services Commission [Art. 139(4)]; and the Attorney General [Art. 145(1)]. The other important function of the YDPA is the proclamation of emergency pursuant to Art. 150, Federal Constitution.

In short, the YDPA is conferred with an extensive list of powers. However, the Federal Constitution restricts the powers by consistently directing the YDPA to act on the advice of the Prime Minister, or the Ministers or other authorized persons or institutions. This rule is embedded in Art. 40(1A), Federal Constitution and is evident in several court cases. For instance, the Court of Appeal in the case of Dato' Seri Anwar Ibrahim vs. Public Prosecutor ${ }^{23}$ pronounced that the YDPA is required to act on the Prime Minister's advice. The Court further clarified: "[t]he advice envisaged by art. 40(1A) is the direct advice given by the recommender and not advice obtained after consultation."

\section{The Rulers}

The term 'Ruler' is defined in Art. 160, Federal Constitution to embrace two groups of persons, namely the Yang di-Pertuan Besar (for Negeri Sembilan) and any person exercising the functions of the Ruler within the meaning of the respective states' Constitution (i.e. for states other than Negeri Sembilan). According to Art. 70,

\footnotetext{
21 Art. 122B(1), Federal Constitution.

22 Ibid.

23 [2000] 2 CLJ 570.
} 
Federal Constitution, the Rulers take precedence after the YDPA and his Consort. However in other occasions, the Rulers will take precedence over all other persons; and within his own state, the Ruler shall take precedence over the other Rulers. ${ }^{24}$ Further, Art. 3(2), Federal Constitution confers on the Rulers the position of the Heads of the religion of Islam in their own respective states, which are exercisable in accordance with the states' Constitution.

By and large, the provisions regulating the Rulers are spelt out in the constitutions of each state. ${ }^{25}$ Nevertheless, the Eighth Schedule to the Federal Constitution regulates certain important provisions concerning the Rulers. Section 1(2), Eighth Schedule provides that the Ruler has discretionary powers to perform the following functions:

(i) to appoint a Menteri Besar (i.e. Chief Minister);

(ii) to withhold consent to a request for dissolving the state's Legislative Assembly;

(iii) to request the COR for a meeting to discuss issues concerning the privileges, position, honour and dignity of the Rulers or religious matters;

(iv) to perform the function as Head of the religion of Islam or relating to the Malay customs;

(v) to appoint an heir or heirs, consort, Regent or Council of Regency;

(vi) to award titles, honours and dignities; and

(vii) to regulate royal courts and palaces.

Additionally, the Eighth Schedule confers other crucial powers on the Ruler to perform within its own respective state. The Ruler shall, inter alia, appoint an Executive Council [sec. 2(1) and (2)]; constitute the state's Legislature alongside the Legislative Assembly [sec. 3]; summon, prorogue or dissolve the Legislative Assembly [sec. 9]; and assent to the Bills passed by the Legislative Assembly [sec. 11(1)].

Art. 70, Federal Constitution.

25 See for instance, Art. 71(1), Federal Constitution: Any reference as to the right of a Ruler of a State to succeed and to hold, enjoy and exercise his constitutional rights and privileges, and the manner for determining any dispute as to the title to the succession as a Ruler of any State shall only be made to the Constitution of the respective state. 
Except where the Ruler is granted with discretionary powers, the Federal Constitution requires the Ruler to act in accordance with the advice of the Executive Council or of a member thereof acting under the general authority of the Council. ${ }^{26}$ As in the case of the YDPA, sec. 1(1A), Eighth Schedule requires the Ruler when acting 'in accordance with advice or on advice', to accept and act in accordance with such advice.

The unique feature of the Rulers is underlined in Art. 38(1), Federal Constitution, where they shall assemble in the Majlis Raja-Raja or the COR. The provisions regulating the COR are detailed out in the Fifth Schedule. According to sec. 1, the COR consists of the Malay Rulers and the Yang di-Pertua-Yang di-Pertua Negeri (i.e. for states without a Ruler). However, sec. 7 limits the rights of the Yang diPertua-Yang di-Pertua Negeri to partake in any proceedings of the $\mathrm{COR}$ when the meeting is convened to discuss issues concerning the election or removal of the YDPA or his Deputy, the privileges, position, honour and dignity of the Malay Rulers, or the religious acts, observances or ceremonies.

The functions of the COR are provided for in Art. 38, Federal Constitution, which include:

(i) to elect the YDPA and the Deputy YDPA in accordance with the Third Schedule Federal Constitution;

(ii) to agree or disagree to the extension of any religious acts, observances or ceremonies to the whole country;

(iii) to consent or withhold consent to any law and to make or give advice on any appointment in accordance with the Federal Constitution;

(iv) to appoint members of the Special Court under Art. 182(1);

(v) to grant pardons, reprieves and respites, or to remit, suspend or commute sentences, under Art. 42(12);

(vi) to deliberate questions of national policy;

(vii) to consent or withhold consent on the passing of any law directly affecting the privileges, position, honour or dignity of the Rulers; and

(viii) to be consulted before any change in policy affecting administrative action under Article 153 is made.

26 Sec. 1(1), Eighth Schedule, Federal Constitution. 
In many respects, the laws regulating the functions of the Rulers are similar to that of the YDPA. The powers of the Rulers are mainly limited to their respective states; and in the exercise of their functions within the given state, the Rulers are generally required to act on the advice of the Executive Councils or any members of the Councils. Collectively, the Rulers who assemble in the COR assumes a more direct role and functions within the Federation. Primarily, the COR is responsible for electing the YDPA. Other than that, as the determined by the Federal Constitution, the COR assumes powers to give or withhold consent to certain laws and serves as an important institution that must be consulted before any appointment to certain key offices within the Federation could be made.

\section{REASSESSMENT OF THE ROLE OF THE YDPA AND THE RULERS IN THE MAKING OF INTERNATIONAL TREATIES}

International treaties, being the primary source of international law, are essentially a subject-matter of international law. The rules regulating the formation and making of international treaties exist in international customs as well as several international treaties. The main treaty regulating this area is the Vienna Convention 1969, which is also participated by Malaysia. ${ }^{27}$ Nonetheless, to understand treaties by relying exclusively on the provisions of the international law may not be sufficient. In other words, reference must also be made to the local laws. Moreover, the Vienna Convention 1969 acknowledges the importance of the local laws in determining the legality of treaties signed for the State. ${ }^{28}$ In Malaysia, the Federal Constitution also inculcates certain provisions dealing with international treaties. The following discussion will examine some important rules in the making of international treaties as provided for under the Vienna Convention 1969, the Federal Constitution and decided case. Subsequently, the discussion will reassess the roles and functions of the YDPA and the Rulers in the making of international treaties based on the available authorities.

\footnotetext{
27 Malaysia acceded to the Vienna Convention 1969 and became a party to the same on 27 July 1994.

28 See for instance, Art. 46, Vienna Convention 1969.
} 


\section{Treaty-Making under the Vienna Convention 1969}

Art. 6, Vienna Convention 1969 grants the rights on every sovereign State to conclude international treaties. The making of treaties symbolizes States' independence and sovereignty. This is in line with Art. 1, Convention on Rights and Duties of States 1933 ('Montevideo Convention'), which underlines the legal criteria of statehood, namely a permanent population, a defined territory, a government and the capacity to enter into relations with the other States. The latter implies the rights of a sovereign State to conclude international treaties with its counterparts.

TheState's representative for the purpose of adopting or authenticating the text of a treaty or for expressing the consent of the State to be bound by a treaty is explained in Art. 7, Vienna Convention 1969. Paragraph (1)(a) lays down the general rule that requires the person representing a State to tender appropriate full powers indicating his authority to adopt, authenticate or express consent to the treaty. However, such requirement may be dispensed with if it can be inferred from the State's practice that the State intends to acknowledge the person as its representative for the purpose mentioned above. ${ }^{29}$

In addition, the Vienna Convention 1969 expressly recognizes three groups of persons who, by reason of their functions, are considered as representing their States, and are excluded from producing appropriate full powers. Art. 7(2) categorizes these persons into three groups, namely (a) the Heads of State, Heads of Government and Ministers for Foreign Affairs; (b) heads of diplomatic missions; and (c) the representatives accredited by States to an international conference or to an international organization. The exclusion from producing full appropriate powers granted to the first group of persons extends to all necessary acts for concluding treaties. The same exemption is granted to the second and third group of persons but only for the purpose of adopting the text of treaties within their respective missions.

The effect of a treaty concluded by a person not having the appropriate authority to represent a State is further explained in Art. 8, Vienna

$29 \quad$ Art. 7(1)(b), Vienna Convention 1969. 
Convention 1969. In principle, such treaty carries no legal effect on the respective State, unless the State decides to affirm it.

\section{Treaty-Making under the Federal Constitution}

The starting point for discussing the treaty-making power in Malaysia must begin by drawing references to Arts. 74, 76 and the Ninth Schedule of the Federal Constitution. Art. 74(1) reads: "Parliament may make laws with respect to any of the matters enumerated in the Federal List or the Concurrent List (that is to say, the First or Third List set out in the Ninth Schedule)." A cross reference to section 1 of List I (Federal List) in the Ninth Schedule shows the "external affairs' as one of the areas falling under the legislative lists of the Parliament. The subject-matters included in the external affairs are, inter alia, treaties, agreements and conventions with other countries and the implementation of treaties, agreements and conventions with other countries. ${ }^{30}$ Meanwhile, Art. 76(1)(a) confers on the Parliament the extended powers to make laws for all constituent states in Malaysia for the purpose of implementing any treaty, agreement or convention between Malaysia and any other country, or any decision of an international organization of which Malaysia is a member.

Two points may be deduced from the above provisions. Firstly, the Federal Constitution expressly confers on the Federal Parliament, vis-à-vis the Legislative Assembly of the constituent states, the sole power to legislate on treaties. Secondly, the wordings used in Arts. 74(1) and 76(1)(a) restrict the Parliament's power to enact laws on international treaties, i.e. a legislative function. ${ }^{31}$ In other words, the power of the Parliament does not extend to executing or concluding the treaties.

Unlike the Parliament which is delimited to exercise the legislative functions, the Federal Constitution does not expressly describe the

30 See further section 1, List 1 (Federal List), Ninth Schedule, Federal Constitution.

31 See, especially, Art. 73(a), Federal Constitution: "In exercising the legislative powers conferred on it by this Constitution - (a) parliament may make laws for the whole or any part of the Federation and laws having effect outside as well as within the Federation". 
scope of the executive authority. Art. 80(1), Federal Constitution reads: " $[\ldots]$ the executive authority of the Federation extends to all matters with respect to which Parliament may make laws [...]." This provision confers on the executive body (at the Federal level) the right to exercise legal powers on the subject-matters listed in the Federal List and the Concurrent List to the Ninth Schedule. As stated earlier, they include the external affairs, covering treaties, agreements and conventions with other countries and the implementation of those treaties, agreements and conventions.

In explaining the nature and scope of the executive authority, Bari, for instance, stated that the executive powers are far-reaching and cover "the residue of governmental function that remains after legislative and judicial functions are taken away". ${ }^{32}$ For examples, the executive may legally exercise power to implement national policies, maintain peace and security, supervise the civil service and determine foreign policies. ${ }^{33}$ Accordingly, it can be established that the executive organ at the Federal level (i.e. Government of the day) assumes the effective powers to execute and conclude international treaties.

The manners for exercising the executive authority is further explained in Arts. 39 and 40, Federal Constitution. Art. 39 provides that the executive authority of the Federation shall be vested in the YDPA and exercisable by him or by the Cabinet or any Minister authorized by the Cabinet. However, Art. 40(1) and (1A) requires the YDPA, in the exercise of the executive functions, to accept and act in accordance with the advice of the Cabinet or of a Minister acting under the general authority of the Cabinet.

32 Bari (2003); See also in Basu, D. Das. (1999). Introduction to the constitution of India (18th ed.). Nagpur: Wadhwa and Company; Johari, J. C. (2007). The constitution of India: A politico-legal study (4th ed.). New Delhi: Sterling Publishers Private Limited; Somanathan, T. V. (2016). The administrative and regulatory state. In S. Choudhry, M. Khosla, \& P. B. Mehta (Eds.), The Oxford handbook of the Indian constitution (pp. 386-411). Oxford: Oxford University Press. This definition of the 'executive authority' was enunciated by Mukherjea CJ in the Indian case of Ram Jawaya Kapur vs. State of Punjab (1955) AIR 549 (Supreme Court).

33 Bari (2003). 


\section{The Case of Government of the State of Kelantan vs. the Government} of the Federation of Malaya and Tunku Abdul Rahman Putra AlHaj. $^{34}$

On 10 September 1963, just six days before the historic formation of Malaysia, the Government of the State of Kelantan instituted an action against the Federal Government for declarations that the Malaysia Agreement 1963 and the Malaysia Act were null and void, or alternatively were not binding on the State of Kelantan. The Malaysia Agreement 1963 was signed in July 1963 between the Governments of the Federation of Malaya, the United Kingdom, Sarawak, North Borneo and Singapore. The Agreement would bring Singapore, Sabah and Sarawak to federate with the existing eleven states of the Federation of Malaya (including the State of Kelantan) to form the Federation of Malaysia. The Malaysia Act was subsequently passed by the Federal Government to amend the Federal Constitution and gives domestic legal effect to the Malaysia Agreement 1963.

The State of Kelantan challenged the legality of the Malaysia Agreement 1963 and the Malaysia Act on the following grounds:

(i) the Malaysia Act would violate the Federation of Malaya Agreement 1957 by abolishing the 'Federation of Malaya';

(ii) the proposed changes needed the consent of each constituent state including the State of Kelantan, and this had not been obtained;

(iii) the Sultan of Kelantan should have been made a party to the Malaysia Agreement 1963;

(iv) the constitutional convention dictates that consultation with the Rulers of individual states was required before substantial changes can be made to the Constitution; and

(v) the Federal Parliament had no power to legislate for the State of Kelantan in matters that the state could legislate on its own.

Thompson CJ who presided over the proceedings, rejected the claim by the State of Kelantan. In delivering his judgment, the judge pronounced, inter alia:

34 [1963] MLJ 355 (High Court). 
"The Malaysia Agreement is signed 'for the Federation of Malaya' by the Prime Minister, the Deputy Prime Minister and four other members of the Cabinet. This was in compliance with Articles 39 and 80(1) of the Constitution and there is nothing whatsoever in the Constitution requiring consultation with any State Government or the Ruler of any State."

Accordingly, the Court in the above landmark case acknowledged the authority of the Cabinet members (being the executive arm of the Federal Government) to sign a treaty without the need to conduct prior consultation with the Rulers.

\section{Reassessing the Roles of the YDPA and the Rulers in the Making of International Treaties}

The explanation on the legal provisions referred to above provides some basic ideas and structures in reassessing the roles of the YDPA and the Rulers in making international treaties.

Generally, the Federal Constitution provides no clear provisions on granting treaty-making capacity to the YDPA. As previously discussed, the functions conferred on the YDPA extends to the executive, legislative and judicial tasks; but for the majority parts, the YDPA is required to exercise his functions by observing the advice of the Prime Minister or the Cabinet of Ministers. Likewise, the Rulers at the state level must also act according to the advice of each respective Executive Council. The Federal Constitution also regulates for the COR, which constitutes the Malay Rulers. In principle, the COR does not occupy the extensive functions like the YDPA. In many respects, the roles of the COR are consultative in nature and its functions are mostly restricted to matters affecting the Malays, the Rulers and the religion of Islam.

However, the power of the Monarchs to conclude treaties is not new and unusual. Historically, the Royals, especially the Malay Rulers, performed the ultimate role in executing treaties with foreign sovereigns. This is evident from the large number of old treaties and documents executed by the Malay Rulers. For instances: ${ }^{35}$

35 See Institute Terjemahan Negara Malaysia Berhad. (2008). Perjanjian 
(i) His Highness Sultan Hussain Mahomed Shah (Sultan of Johore) signed a treaty of friendship and alliance with the East India Company in 1824;

(ii) Their Highnesses Sultan Idris (Sultan of Perak), Sultan Abdul Samad (Sultan of Selangor), Sultan Ahmad (Sultan of Pahang), Tuanku Muhammad ibni Tuanku Antah (Yam Tuan Besar of Sri Menanti) signed the Treaty of Federation 1895 with the Governor of the Straits Settlements (acting on behalf of Her Majesty the Queen, Empress of India);

(iii) His Highness Tungku Long Senik (Raja of Kelantan), on behalf of the Government of Kelantan, signed an agreement with the Government of Great Britain (represented by His Excellency the High Commissioner for the Protected Malay States) in 1910;

(iv) His Highness Syed Putra Jamahillil (Raja of Perlis) signed an agreement with His Majesty's Government within the United Kingdom of Great Britain and Northern Ireland (represented by Harold MacMichael) in 1945; and

(v) Eight Malay Rulers (Pahang, Negeri Sembilan, Selangor, Kedah, Perlis, Kelantan, Terengganu and Perak), the Regent of Johore (who was representing the Sultan of Johore), the Ruling Chiefs of Negeri Sembilan and Sir Donald Charles MacGillivray (on behalf of Her Majesty the Queen) signed and concluded the Federation of Malaya Agreement 1957.

Following the Independence in 1957 and the coming into force of the Federal Constitution, a few rules were incorporated (either directly or indirectly), which has affected the power of the Monarchs to make treaties. The Monarchs, namely the YDPA and the Rulers, are restricted to act within the limits permitted by the Federal Constitution and each respective state's Constitution, as the case may be.

In principle, the Rulers are not qualified to conclude a treaty on behalf of the State under both the Federal Constitution and the international law. At the international level, the Vienna Convention 1969 recognizes the capacity of every sovereign State to conclude

\& dokumen lama Malaysia 1791 - 1965; Old treaties \& documents of Malaysia 1791 - 1965. Kuala Lumpur: Institut Terjemahan Negara Malaysia Berhad. 
treaties. ${ }^{36}$ What constitutes a 'State' were not stated in the Convention. The criteria of statehood under international law was defined under Art. 1, Montevideo Convention. An entity is qualified as a 'State' if it is able to conduct its own external affairs. In the context of Malaysia, the Governments at the state level do not meet this criterion. This is because, by virtue of Art. 74(1) and List I (Federal List) of the Ninth Schedule, the Federal Constitution places the subject-matter of external affairs (including treaties) under the purview of the legislative and executive branches of the Federal Government. In other words, the Federal Constitution only empowers the Federal Government, as opposed to the constituent state Governments, to deal with the international agreements. It follows that the Rulers as Heads of State at the state level, albeit exercising the executive functions, are evidently not conferred with the power to conclude international treaties. The Rulers are excluded from the meaning of 'State' in the eyes of international law.

However, the above inference does not apply to the YDPA. Unlike the Rulers, the YDPA exercises functions at the Federal level. He is the Supreme Head of the Federation [Art. 32(1)] and part of the executive branch of the Federal Government [Art. 39]. The international law recognizes the YDPA's authority as the representative of a State for concluding international treaties, even without the need of providing full appropriate powers. This is in Art. 7(2)(a), Vienna Convention 1969 which recognizes the Head of the State, Head of the Government and the Minister for Foreign Affairs as legal representatives of the States in carrying all necessary acts for concluding treaties. In the context of Malaysia, the Head of State refers to the YDPA as the Supreme Head of the Federation (Art. 32(1), Federal Constitution), the Head of the Government refers to the Prime Minister that presides over the Cabinet of Ministers (Art. 43(2)(a), Federal Constitution) and the Foreign Minister being a member of the Cabinet (Art 43(1) and (2)(b), Federal Constitution). Collectively, they form the executive branch of the Federal Government in pursuant to Art. 39, Federal Constitution. By literal reading of Art. 7, Vienna Convention 1969 and Art. 39, Federal Constitution, the YDPA may be said to possess the appropriate power to sign international treaty.

Essentially, the Cabinet, which is formed on the basis of party politics, exercises the effective executive power. ${ }^{37}$ The Cabinet is

36 Art. 6, Vienna Convention 1969.

37 Ahmad, S. S. S. (2007). Malaysian legal system (2nd ed.). Kelana 
constituted of Ministers, collectively known as the Jemaah Menteri (Cabinet of Ministers) and is headed by a Prime Minister appointed by the YDPA..$^{38}$ In practice, the YDPA does not possess the power to conclude international treaties, rather they are entered into for the Government of Malaysia by the Prime Minister, Foreign Minister and such other authorized Ministers. This conclusion is derived from the reading of Arts. 39 and 40(1) and (1A) of the Federal Constitution discussed earlier. Bari's observation also supports the above conclusion. He reiterated that although the executive authority is vested on the Heads of State (i.e. the YDPA and the Rulers), but the constitutional democracy requires that the right to rule or make important decisions be given to the Government of the day (i.e. the Cabinet). ${ }^{39}$ As the popularly elected government, the Cabinet is responsible for the country's administration and shall be accountable to the people. ${ }^{40}$ Meanwhile, the YDPA and the Rulers perform a formal role as a symbol of unity and authority and are required to act on the advice of the Cabinet or the Executive Councils. ${ }^{41}$

Although the YDPA has no authority to make a treaty, a careful examination of the Federal Constitution shows few avenues where the YDPA or the Rulers (including the COR) may exercise functions in the country's administration. The exercise of these functions may include influencing the making of international treaties.

Firstly, Art. 38(2), Federal Constitution authorizes the COR to discuss and consider matters relating to the national policies or on any other issues as the COR thinks fit. The Federal Constitution allows for the deliberation on matters concerning the national policy to be made in the presence of the YDPA and the Rulers. However, clause (3) places certain restrictions on the COR in exercising this right. Technically, the YDPA is required to be accompanied by the Prime Minister, while the Rulers and the Yang di-Pertua-Yang di-Pertua

Jaya: LexisNexis; Yatim, R. (1995). Freedom under executive power in Malaysia: A study of executive supremacy. Kuala Lumpur: Endowment, p. 28: The real executive power vests in the Prime Minister who heads the Cabinet.

38 Art. 43(2)(a) and (b), Federal Constitution.

39 Bari (2003).

40 Ibid.

41 Ibid. 
Negeri shall be accompanied by their respective Chief Ministers. In terms of the substance of the meeting, the deliberation shall be among the functions exercised by the YDPA (acting on the advice of the Cabinet) and the Rulers and the Yang di-Pertua-Yang di-Pertua Negeri (acting in accordance with the advice of their respective Executive Councils).

Secondly, the Federal Constitution allows the YDPA to be updated on the administrative affairs of the country. Art. 40(1) states that the YDPA, while carrying out the executive functions, "shall be entitled, at his request, to any information concerning the Government of the Federation which is available to the Cabinet." This occasion may serve as a platform for the YDPA to inquire about updates on the country's administration and to voice his views and give advice on the same. The topics could be anything, including matters relating to the conclusion of treaties.

Thirdly, the Federal Constitution makes several references to the requirement of conducting consultation with or obtaining consent from relevant state Governments or the COR (as the case may be) before any decision could be made or any law could be enacted. This reference imposes certain functions on the Rulers-being part of the state Governments and members of the COR-to influence decisions made by the Federal Government, including matters relating to international treaties.

In light of the present discussion, the reference to Art. 38, Federal Constitution is central in explaining the scope and functions of the COR, which is composed of the Malay Rulers. As stated earlier, Art. $38(2)$ (c) confers on the COR the right to give or withhold consent to the making of any law as determined by the Federal Constitution. Clause (4) further qualifies that the consent of the COR must be obtained when the law to be passed directly affects the privileges, position, honour or dignity of the Rulers. ${ }^{42}$

Albeit the provision conferring on the COR the power to agree on a proposed law, its application is limited and does not extend

42 See also Art. 38(6)(c), Federal Constitution: In the exercise of his functions in any proceedings of the COR, a Ruler may act on his own discretion when giving or withholding consent to any law affecting the privileges, position, honour or dignity of the Rulers. 
to the right of giving or withholding consent to make international treaties. The consent of the COR shall only be obtained if the law to be introduced has domestic legal effect. Conversely, the signing of international treaties introduces particular law at the international level. International treaties are not a direct source of local law, rather they are part of international law, ${ }^{43}$ where it creates rights and obligations on the State-parties in their international relationship. ${ }^{44}$ In the context of Malaysia, the meaning of 'law' is defined in Art. 160, Federal Constitution to include written law, the common law which is legally operative in Malaysia and any custom or usage having the force of law in Malaysia. The written law consists of the Federal Constitution and the State Constitutions, legislation enacted by the Parliament and the State Legislative Assemblies, subsidiary legislation made by the authorized persons or bodies and emergency Ordinances made by the YDPA. ${ }^{45}$ It follows that, international treaties are excluded from the meaning of 'law' under the purview of Art. 38, Federal Constitution.

This position reflects the practice of Malaysia which leans towards the dualistic approach by treating international treaties as separated from the national legal system. ${ }^{46}$ An international treaty has no domestic legal force unless it is expressly transformed (i.e. adopted) as part of the national law. The doctrine of transformation dictates that an act of transformation via express means of local legislation or an Act of Parliament, known as the enabling Act, is needed to transform treaties into the local laws. ${ }^{47}$ By referring to Art. 38(2) (c) and (4), Federal Constitution, it is only at this stage, i.e. when

43 Art. 38(1), ICJ Statute: "The Court [International Court of Justice], whose function is to decide in accordance with international law such disputes as are submitted to it, shall apply: (a) international conventions, whether general or particular, establish rules expressly recognized by the contesting states; (b) ..."

44 Art. 26, Vienna Convention 1969 incorporates the doctrine of pacta sunt servanda and imposes an obligation on all State-parties to perform every treaty in force in good faith.

45 Aun, W. M. (2005). The Malaysian legal system (3rd ed.). Petaling Jaya: Pearson Malaysia Sdn. Bhd., pp. 109-121; Pheng, L. M. (2005). General principles of Malaysian law (5th ed.). Shah Alam: Penerbit Fajar Bakti Sdn. Bhd., pp. 17-41.

46 Hamid (2019).

47 Shaw, M. N. (2014). International law (7th ed.). Cambridge: Cambridge University Press, p. 100. 
the Parliament wants to introduce a treaty locally, that the consent from the COR must be obtained if the enacted provisions of the treaty directly affects the privileges, position, honour or dignity of the Rulers. Otherwise, consent of the COR is not required to be obtained if the situation falls outside the scope of Art. 38, Federal Constitution.

The other crucial provision is Art. 76, Federal Constitution which explains the scope of consultation with the state Government. Generally, Art. 76(1)(a) permits the Parliament to make laws falling under the State List of the Ninth Schedule for the purpose of implementing any treaty, agreement or convention between the Federation and any other country. Clause (2) limits such power by imposing a mandatory requirement for the state Government concerned to be consulted if the proposed law deals with the Islamic law or the Malay customs. In this context, the Ruler as the Head of State must be consulted, especially when he assumes the position of the Head of the religion of Islam and the Malay customs in his own state. $^{48}$

However, this provision must be viewed with limitation. This is because the requirement for consulting the state Government shall only take effect when the Federal Government decides to introduce international treaties locally, and not at the time when the Federal Government signs international treaties. Besides, Art. 76 merely imposes the requirement of conducting consultation, vis-à-vis obtaining consent from, the state Government. On this point, Jewa notes that the requirement for 'consultation' does not in any way implies 'consent'. ${ }^{49}$ As such, even if the Federal Government is required to consult the state Government, the former is not bound to follow the views expressed in the course of such consultation..$^{50}$ Moreover, the consultation with the state Government only becomes mandatory when it is required under the Federal Constitution. On the contrary, where the Federal Constitution makes no reference to the need of conducting consultation, no such obligation for

\footnotetext{
48 See further Art. 3(2) and Section 1(2)(d), Eighth Schedule, Federal Constitution.

49 Jewa, T. S. (1996). Public international law: A Malaysian perspective (Volume I). Kuala Lumpur: Pacifica Publications.

50 Ibid.
} 
conducting consultation may be implied. ${ }^{51}$ This observation further weakens the impact of Art. 76, Federal Constitution, in so far as the consultation with the state Government (which includes the Rulers) is concerned.

At the international level, the importance of the consultation process in the making of international treaties can be summarised from just a few contexts. For example, the significance of consultation is implied from the practice of ratification. Art. 14, Vienna Convention 1969 recognizes ratification as one of the legal means for expressing consent to be bound by treaties. ${ }^{52}$ Hamid stated that ratification provides an opportunity for the contracting States to self-reflect by re-examining all ensuing effects and benefits of the treaty. ${ }^{53}$ Likewise, the process allows the Government appropriate space and time for carrying out consultations with interested persons or groups concerning the obligation that the State is about to undertake. ${ }^{54}$ Therefore, if a treaty is signed subject to ratification, those parties who are required to be consulted, may use the platform to offer views and advice to the Government before any further act of ratifying a treaty is completed.

In other instance, a State's domestic law may require consultation with relevant institutions as precondition before the Government signs an international treaty. If this is the requirement, then, failure to conduct the necessary consultation may be a valid ground to invalidate the concluded treaty. This inference is derived from Art. 46(1), Vienna Convention 1969. The provision reads: "[a] State may not invoke the fact that its consent to be bound by a treaty has been expressed in violation of a provision of its internal law regarding competence to conclude treaties as invalidating its consent unless that violation was manifest and concerned a rule of its internal law of fundamental importance." In this context, Art. 46(1) allows a state to avoid a treaty concluded on its behalf on the pretext that the treaty was made in clear breach of the required internal procedures

51 Ibid.

52 See further Art. 2(1)(b), Vienna Convention 1969: ratification means "the international act so named whereby a State establishes on the international plane its consent to be bound by a treaty".

53 Hamid (2019).

54 Ibid. 
of a state's domestic laws. These domestic procedures may include conducting consultation with the relevant institution or organs.

The grounds allowed for invalidating treaties for failure to observe States' internal consultative procedures may be illustrated in several cases. Before the entry into force of the Vienna Convention 1969, the Senate of the United States challenged the validity of the 1975 bilateral agreement between the United States and Israel in connection with the latter's withdrawal from the Sinai Peninsula. ${ }^{55}$ Under the said agreement, the United States committed to aid Israel in fulfilling their supply needs and defense requirements. The Senate alleged that the agreement had no force of law, both at the domestic and international levels. It was because the Government concluded the agreement bypassing the advice and consent of the Senate, which were crucial procedures under the State's constitution. ${ }^{56}$ However, the Senate's contention was met with rejection by the Department of the State, to which the former did not take further action. ${ }^{57}$ In 1990, Iraq challenged the presumed boundary between her and Kuwait as established in the 1963 bilateral agreement. ${ }^{58}$ The validity of the said agreement was questioned by Iraq on the grounds that, inter alia, the Government's agreement was made in the absence of the Iraqi Parliament's approval. However, the allegation by Iraq was subsequently rejected. ${ }^{59}$

55 Israel Ministry ofForeignAffairs. 112 Israel-United States Memorandum of Understanding- 1 September 1975. Retrieved from https://mfa.gov. $\mathrm{il} / \mathrm{mfa} /$ foreignpolicy/mfadocuments/yearbook2/pages/112\%20israelunited $\% 20$ states $\% 20$ memorandum $\% 20$ of $\% 20$ understandi.aspx.

56 Art. II, S. 2, the United States Constitution grants the power on the President to make treaties with the advice and consent of the Senate. Unless the Senate (i.e. two-thirds of the Senators present) has given its advice and consent to such treaty, the treaty is not valid on the United States.

57 Meron, T. (1978). Article 46 of the Vienna Convention on the Law of Treaties (Ultra Vires Treaties): Some Recent Cases. British Yearbook of International Law, 49(1). 175-199.

58 The agreement entitled the Agreed Minutes Regarding the Restoration of Friendly Relations, Recognition and Related Matters, signed on 4 October 1963 (Baghdad, Iraq), Serial No. 485 UNTS 321.

59 See further Mendelson, M.H. and Hulton, S.C. (1990). The Iraq-Kuwait boundary: Legal aspects. Rev. BDI, 23293. 
In the context of Malaysia, there is no such provision in the Federal Constitution (including Art. 76) which requires prior consultation with the Rulers or the COR before the Federal Government decides to sign or ratify a treaty. In the absence of such provision, an international treaty may be validly signed and concluded even without prior consultation with the Rulers or the COR. This was the established position as decided by the court in the landmark case of Government of the State of Kelantan v. the Government of the Federation of Malaya and Tunku Abdul Rahman Putra AlHaj discussed earlier. In accordance therefore Article 46(1), of the Vienna Convention 1969 failed to invalidate a treaty by reason that the consultation process with the interested parties (which included the Rulers) was not evident.

\section{CONCLUSION}

In concluding, the monarchy is an important institution in Malaysia. The monarchs are the focus or symbol of identity in the country. ${ }^{60}$ At the same time, the Federal Constitution grants crucial powers on the YDPA, the Rulers and the COR affecting the country's administration. Nonetheless, these powers are within the limits and scope as determined by the Federal Constitution. For most of the time, the YDPA is required to act in accordance with the advice of the Prime Minister or the Cabinet of Ministers. Likewise, the Rulers are required to act on the advice of the state's Executive Council or of a member thereof. On this premise, scholars such as Bari, is of the view that the YDPA and the Rulers normally perform symbolic and ceremonial functions. ${ }^{61}$ In other words, the Monarchs usually do not interfere in the country's day-to-day administration, unless in the manner authorized by the Federal Constitution or the state's Constitution as the case may be.

In the context of treaty-making, the YDPA and the Rulers have no legal capacity to make and conclude international treaties. Although this is the position practised in Malaysia, the YDPA and the Rulers can still influence the making of international treaties. The YDPA and the Rulers (which also cover the COR) may offer their viewpoints,

60 Harding (1996), p. 62.

${ }_{61}$ Bari (2003). 
feedback and advice to the Cabinet concerning a proposed treaty. This function may appear insignificant, but they do have a basis in several legal provisions and may carry certain weight. Simply put, negating entirely the roles of the YDPA and the Rulers in the making of treaties may not be appropriate because international treaties do not merely operate at international level, but they may still regulate the domestic affairs that interfere with the position, function and role of the YDPA and the Rulers.

The extent to which the YDPA and the Rulers may persuade the making of international treaties is rather difficult to measure precisely. Moreover, the Federal Constitution merely requires the YDPA (or the Rulers) to accept the advice of the Cabinet of Ministers (or the Executive Council), and not the other way around. Notwithstanding the above, the influence of the YDPA and the Rulers in the country's administration in general is exigent. In particular, the Federal Constitution places the YDPA and the Rulers as taking precedence over all persons in Malaysia, including the Prime Minister, Chief Ministers, Ministers and members of the states' Executive Council. Although the above reference is merely restricted to the priority and position of the YDPA and the Rulers, as opposed to their views and opinions, there is always a feeling of deference, approval and liking among Malaysians towards the ideas, suggestions and viewpoints of the Monarchy because of their status in society. To put it in a different context, the views and opinions of the YDPA or the Rulers on matters relating to the country's administration may produce a sentiment of respect among the administrators or the Government of the day, which shall be recognized as important and be given due consideration before any administrative action can be taken. Logically, if the highest-ranked person in the country asks for something done, would one normally oppose?

In the past, there have been a number of instances where the YDPA and the Rulers were 'called' to intervene in the country's administration. For example, former Prime Minister Tun Dr. Mahathir led the 'Save Malaysia' movement demanding the interference from the YDPA and the COR to remove the then Prime Minister Najib Razak from his office following the $1 \mathrm{MDB}$ scandal. ${ }^{62}$ The petition called 'the

62 Tan, C.K. (2016, March 28). Mahathir calls for submitting 1M signatures to oust Najib. Nikkei Asian Review. Retrieved from https:// asia.nikkei.com/Politics/Mahathir-calls-for-submitting-1m-signaturesto-oust-Najib; Wahari, H. and Zul, S. A. (2016, September 15). Malaysia's king, Mahathir hold rare talks over petition seeking PM Najib's removal. Benar News. Retrieved from https://www.benarnews. 
Citizen's Declaration' was handed over to the then YDPA during a closed meeting at Istana Anak Bukit, Alor Setar in September 2016. However, it was reported that the King refused to get involved in removing Prime Minister Najib via the petition, claiming that the removal of the Prime Minister can only be done within the ambit of the Federal Constitution. ${ }^{63}$

Similar situations could have come from the state level. The Rulers have on numerous occasions, exerted their authority in appointing the Chief Ministers although these decisions seemed to be against the will of the political parties. One of the noteworthy incidents took place in Selangor when the Sultan of Selangor finally decided to appoint Azmin Ali over Wan Azizah as the new Chief Minister in 2014 following the resignation of Tan Sri Khalid Ibrahim. ${ }^{64}$ In Perlis, the conflict occurred when the King of Perlis re-appointed Datuk Seri Azlan Man as the Chief Minister following the 14th General Election to the displeasure of the Perlis Barisan Nasional leadership. ${ }^{65}$ The recent crisis in the appointment of the Chief Minister took place in Johor in April 2019 when Prime Minister Mahathir and the Ruler of Johor both exerted their authority in having the final say over the appointment and removal of the Chief Minister. ${ }^{66}$ The episode saw

org/english/news/malaysian/mahathir-meeting-09152016203927. html; Tan, J. (2016, September 25). Dr. M's audience with the king. The Star Online. Retrieved from https://www.thestar.com.my/opinion/ columnists/analysis/2016/09/25/dr-ms-audience-with-the-king-tun-drmahathir-mohamad-got-his-wish-but-he-did-not-get-his-way-whenhe.

63 Wahari and Zul (2016, September 15); Tan (2016, September 25).

${ }^{64}$ Osman, M. N. M., Sun, O. E., Pasuni, A., \& People's Justice Party, P. K. R. (2014). The Selangor Chief Minister Crisis and the Future of Pakatan Rakyat (PR). Malaysia Update.

65 Loh, A. and Chern, L.T. (2018, May 24). Azlan Man sworn in as Perlis MB for second term. The Star Online. Retrieved from https:// www.thestar.com.my/news/nation/2018/05/24/azlan-man-swornin-as-perlis-mb-for-second-term; Crisis in Perlis resolved as all BN assemblymen now backs Menteri Besar. (2018, June 5). The Straits Times. Retrieved from https://www.straitstimes.com/asia/se-asia/crisisin-perlis-resolved-as-all-bn-assemblyman-now-backs-menteri-besar.

66 Maria. A. (2019, April 11). Bitter feud between Dr Mahathir and the Johor royal family rages on. The Independent. Retrieved from http:// theindependent.sg/bitter-feud-between-dr-mahathir-and-the-johorroyal-family-rages-on/; Malaysia swears in new Chief Minister of state of Johor, Dr Sahruddin Jamal. (2019, April 14). South China Morning 
the resignation of Datuk Osman Sapian (an ally of Prime Minister Mahathir) and the appointment of Dr. Sahruddin Jamal as the new Chief Minister. Besides, the interference from the Rulers was also evident in a few other administrative matters. For instance it was reported that the Sultan of Selangor had an audience with four Selangor non-Muslim state executive councilors in August 2019 to clear up the issue of a proposed amendment to a state enactment on the religious conversion of minors. ${ }^{67}$

The Monarch's interference in the making of international treaties was evident following the Government's accession to the Rome Statute. The Minister of Foreign Affairs was upon request to present before the YDPA, Al-Sultan Abdullah Ri'ayatuddin Al-Mustafa Billah Shah ibni Sultan Haji Ahmad Shah Al-Musta'in Billah, at the Istana Negara on 12 March 2019 to update His Majesty the King on Malaysia's participation in the Rome Statute. ${ }^{6}{ }^{2}$ Following the meeting, the YDPA advised the Minister to clarify to the public on certain points concerning the decision to accede to the Rome Statute.

They include: ${ }^{69}$

(i) the chronology of events leading to Malaysia's accession to the Rome Statute;

(ii) the benefits to the country for participating in the Rome Statute;

Post. Retrieved from https://www.scmp.com/news/asia/southeastasia/article/3006102/malaysia-swears-new-chief-minister-state-johordr; Mahathir v Johor royals: timeline of recent spat. (2019, May 3). The Straits Times. Retrieved from https://www.straitstimes.com/asia/ se-asia/mahathir-v-johor-royals-timeline-of-recent-spat.

67 Muthiah, W. (2019, August 8). Four non-Muslim S'gor exco members meet sultan to voice concerns over conversion bill. The Star Online. Retrieved from https://www.thestar.com.my/news/nation/2019/08/08/ four-non-muslim-s039gor-exco-members-meet-sultan-to-voiceconcerns-over-conversion-bill; Selangor non-Muslim exco members attend audience with sultan. (2019, August 8). The Sun Daily. Retrieved from https:/www.thesundaily.my/local/selangor-non-muslim-excomembers-attend-audience-with-sultan-HC1235229; Ruzki, R. M. and Arshad, N. (2019, August 11). 4 exco menghadap Sultan Selangor. BH Online. Retrieved from https://www.bharian.com.my/berita/ nasional/2019/08/594025/4-exco-menghadap-sultan-selangor.

68 Prime Minister's Office of Malaysia. (2019, March 13).

69 Ibid. 
(iii) the status and immunities of the YDPA under the Rome Statute; and

(iv) the requirement for consulting the COR before the Government decides to accede to the Rome Statute.

The fact that such an issue drew the interest of the YDPA, and that His Majesty, the King offered his viewpoints on how to address the matter to the public, signalled that the YDPA may still exercise influence in the making of (or the aftermath of the signing) of international treaties.

Based on the cases highlighted, there is a strong probability that the YDPA and the Malay Rulers could be 'called' to interfere in the making of international treaties, especially when the treaties (e.g. ICERD) encroach on the rights of the Malays, the bumiputeras and the religion of Islam. In particular, the YDPA and the Rulers assume crucial roles in the country's administration, especially as they are the protector of the religion, the preserver of the nation and the symbol of unity. Such interference may not necessarily take place during the early stage of the signing of an international treaty, rather they may be made after the treaty is signed, which has been proven to be effective as illustrated in the accession to the Rome Statute. Since the YDPA and the Rulers assume the highest-ranked position in the country, it would be unacceptable to see how their viewpoints and opinions be dismissed or not given due consideration. Can the YDPA ask the Government not to sign or conclude a treaty for the betterment of the country? Alternatively, can the YDPA influence the Government to withdraw from a particular treaty?

\section{REFERENCES}

Ahmad, S. S. S. (2007). Malaysian legal system (2nd ed.). Kelana Jaya: LexisNexis.

Aun, W. M. (2005). The Malaysian legal system (3rd ed.). Petaling Jaya: Pearson Malaysia Sdn. Bhd.

Bantah TPPA. (2016, January 27), Bantah TPPA's response to Mustapa's speech. MalaysiaKini. Retrieved from https:// www.malaysiakini.com/letters/328359

Bari, A. A. (2003). Malaysian constitution: A critical introduction. Kuala Lumpur: The Other Press. 
Bari, A. A., \& Shuaib, F. S. (2009). Constitution of Malaysia: Text and commentary (2nd ed.). Petaling Jaya: Prentice Hall.

Basu, D. Das. (1999). Introduction to the constitution of India (18th ed.). Nagpur: Wadhwa and Company.

Convention on Rights and Duties of States adopted by the Seventh International Conference of American States, concluded on 26 December 1933, Registration No. 3802 (entered into force 26 December 1934).

Crisis in Perlis resolved as all BN assemblymen now backs Menteri Besar. (2018, June 5). The Straits Times. Retrieved from https://www.straitstimes.com/asia/se-asia/crisis-in-perlisresolved-as-all-bn-assemblyman-now-backs-menteri-besar

Dalton, R. E. (1984). The Vienna Convention on the Law of Treaties: Consequences for the United States. In Proceedings of the ASIL Annual Meeting (Vol. 78, pp. 276-279). Cambridge University Press.

Dato' Seri Anwar Ibrahim v. Public Prosecutor, 2 CLJ 570 (2000).

Dixon, M. (2013). Textbook on international law (7th ed.). Oxford: Oxford University Press.

Federal Constitution.

Garner, B. A. (Ed. in Chief). (2007). Black's law dictionary (8th ed.). Minnesota: Thomson West.

Ghazali, A. Z. Bin. (2019). "Cabaran Institusi Beraja di Malaysia dari Dahulu Hingga Kini." Jabatan Muzium Malaysia, 1-38. Retrieved from http://www.jmm.gov.my/files/Cabaran Institusi Beraja di Malaysia dari Dahulu Hingga Kini_1.pdf

Government of the State of Kelantan v. The Government of the Federation of Malaya and Tunku Abdul Rahman Putra AlHaj, MLJ 355 (High Court) (1963).

Govt not ratifying ICERD. (2018, November 24), The Star Online. Retrieved from https://www.thestar.com.my/ news/nation/2018/11/24/govt-not-ratifying-icerd-we-willcontinue-to-defend-federal-constitution-says-pms-office

Hamid, A. G. @ Khin Maung Sein. (2019).Public international law: A practical approach (4th ed.). Singapore: Sweet \& Maxwell.

Harding, A. (1996). Law, government \& the constitution in Malaysia. Kuala Lumpur: Malaysian Law Journal Sdn. Bhd.

Harding, A., \& Lee, H. P. (Eds.). (2007). Constitutional landmarks in Malaysia: The first 50 years 1957 - 2007. Petaling Jaya: LexisNexis. 
Howard, R. (2016, February 4), Pacific rim trade deal signed, but years of negotiations still to come. Reuters. Retrieved from https://www.reuters.com/article/us-trade-tpp/trans-pacificpartnership-trade-deal-signed-but-years-of-negotiations-stillto-come-idUSKCN0VD08S

Institute Terjemahan Negara Malaysia Berhad. (2008). Perjanjian \& dokumen lama Malaysia 1791-1965 [Old treaties \& documents of Malaysia 1791-1965]. Kuala Lumpur: Institut Terjemahan Negara Malaysia Berhad.

Israel Ministry of Foreign Affairs. 112 Israel-United States Memorandum of Understanding- 1 September 1975. Retrieved from https://mfa.gov.il/mfa/foreignpolicy/mfadocuments/ yearbook $2 /$ pages $/ 112 \% 20$ israel-united $\% 20$ states $\% 20$ memorandum $\% 20 \mathrm{of} \% 20$ understandi.aspx

Jewa, T. S. (1996). Public international law: A Malaysian perspective (Volume I). Kuala Lumpur: Pacifica Publications.

Johari, J. C. (2007). The constitution of India: A politico-legal study (4th ed.). New Delhi: Sterling Publishers Private Limited.

Lim, I. (2017, January 31), US' withdrawal no cause for celebration with Malaysia's anti-TPPA groups. MalayMail. Retrieved from https://www.malaymail.com/news/malaysia/2017/01/31/uswithdrawal-no-cause-for-celebration-with-malaysias-antitppa-groups $/ 1303305$

Loh, A., \& Chern, L.T. (2018, May 24). Azlan Man sworn in as Perlis MB for second term. The Star Online. Retrieved from https://www.thestar.com.my/news/nation/2018/05/24/azlanman-sworn-in-as-perlis-mb-for-second-term

Mahathir v Johor royals: Timeline of recent spat. (2019, May 3). The Straits Times. Retrieved from https://www.straitstimes.com/ asia/se-asia/mahathir-v-johor-royals-timeline-of-recent-spat

Malaysia govt says it won't ratify UN rights treaty after facing anger from malays and muslims. (2018, November 23). The Straits Times. Retrieved from https://www.straitstimes.com/asia/ se-asia/malaysia-govt-says-wont-ratify-rights-treaty-afterfacing-anger-from-malays-and-muslims

Malaysia inks landmark TPPA. (2016, February 5). The Star Online. Retrieved from https://www.thestar.com.my/news/ nation/2016/02/05/malaysia-inks-landmark-tppa-it-joins-11other-nations-in-signing-pact

Malaysia swears in new Chief Minister of state of Johor, Dr Sahruddin Jamal. (2019, April 14). South China Morning 
Post. Retrieved from https://www.scmp.com/news/asia/ southeast-asia/article/3006102/malaysia-swears-new-chiefminister-state-johor-dr

Malaysia withdraws from the Rome statute. (2019, April 5). The Star Online. Retrieved from https://www.thestar.com.my/ news/nation/2019/04/05/malaysia-withdraws-from-therome-statute

Malaysia withdraws from the Rome statute of the international criminal court. (2019, April 5). The Straits Times. Retreived from https://www.straitstimes.com/asia/se-asia/malaysiawithdraws-from-the-rome-statute

Maria. A. (2019, April 11). Bitter feud between Dr Mahathir and the Johor royal family rages on. The Independent. Retrieved from http://theindependent.sg/bitter-feud-between-dr-mahathirand-the-johor-royal-family-rages-on/

Mendelson, M. H., \& Hulton, S. C. (1990). The Iraq-Kuwait boundary: Legal aspects. Rev. BDI, 23, 293.

Meron, T. (1978). Article 46 of the Vienna Convention on the Law of Treaties (Ultra Vires Treaties): Some Recent Cases. British Yearbook of International Law, 49(1). 175-199.

Minister: Govt to ratify convention on racial discrimination, five other treaties in q1 2019. (2018, October 25). Malaysia Today. Retrieved from https:/www.malaysia-today.net/2018/10/25/ minister-govt-to-ratify-convention-on-racial-discriminationfive-other-treaties-in-q1-2019/

Ministry of Foreign Affairs. (2019, March 4). Malaysia accedes to the Rome statute of the international criminal court [Press release]. Retrieved from http://www.kln.gov.my/web/guest/ home2/-/asset_publisher/satu_tab/content/press-releasemalaysia-accedes-to-the-rome-statute-of-the-internationalcriminal-court?inheritRedirect $=$ false

Muthiah, W. (2019, August 8). Four non-Muslim S'gor exco members meet Sultan to voice concerns over conversion bill. The Star Online. Retrieved from https:/www.thestar.com. my/news/nation/2019/08/08/four-non-muslim-s039gor-excomembers-meet-sultan-to-voice-concerns-over-conversionbill

Oppenheim, L. (1955). International Law: A Treatise, vol. 1, edited by H. Lauterpacht. New York: Congmans, Green.

Osman, M. N. M., Sun, O. E., Pasuni, A., \& People's Justice Party, P. K. R. (2014). The Selangor Chief Minister Crisis and the Future of Pakatan Rakyat (PR). Malaysia Update. 
Pheng, L. M. (2005). General principles of Malaysian law (5th ed.). Shah Alam: Penerbit Fajar Bakti Sdn. Bhd.

Prime Minister's Office of Malaysia. (2019, March 13). Kenyataan akhbar berhubung menteri luar negeri menghadap KDYMM Seri Paduka Baginda Yang di-Pertuan Agong [Press release]. Retrieved from https://www.pmo.gov.my/2019/03/kenyataanakhbar-berhubung-menteri-luar-negeri-menghadapkebawah-duli-yang-maha-mulia-seri-paduka-baginda-yangdi-pertuan-agong-kln/

Ruzki, R. M., \& Arshad, N. (2019, August 11). 4 exco menghadap Sultan Selangor. BH Online. Retrieved from https://www. bharian.com.my/berita/nasional/2019/08/594025/4-excomenghadap-sultan-selangor

Schwarzenberger, G. (1949). International law as applied by international courts and tribunals, vol. 1. Stevens \& Sons.

Selangor non-Muslim exco members attend audience with Sultan. (2019, August 8). The Sun Daily. Retrieved from https://www. thesundaily.my/local/selangor-non-muslim-exco-membersattend-audience-with-sultan-HC1235229

Shaw, M. N. (2014). International law (7th ed.). Cambridge: Cambridge University Press.

Somanathan, T. V. (2016). The administrative and regulatory state. In S. Choudhry, M. Khosla, \& P. B. Mehta (Eds.), The Oxford handbook of the Indian constitution (pp. 386-411). Oxford: Oxford University Press.

Statute of the International Court of Justice, signed on 26 June 1945, Serial No. 33 UNTS 993 (entered into force 24 October 1945).

Tan, C. K. (2016, March 28). Mahathir calls for submitting 1M signatures to oust Najib. Nikkei Asian Review. Retrieved from https://asia.nikkei.com/Politics/Mahathir-calls-for-submitting$1 \mathrm{~m}$-signatures-to-oust-Najib

Tan, J. (2016, September 25). Dr. M's audience with the king. The Star Online. Retrieved from https://www.thestar.com.my/ opinion/columnists/analysis/2016/09/25/dr-ms-audiencewith-the-king-tun-dr-mahathir-mohamad-got-his-wish-buthe-did-not-get-his-way-when-he

Vienna Convention on the Law of Treaties, opened for signature 23 May 1969, Registration No. 18232 (entered into force 27 January 1980). 
Wahari, H., \& Zul, S. A. (2016, September 15). Malaysia's king, Mahathir hold rare talks over petition seeking PM Najib's removal. Benar News. Retrieved from https://www. benarnews.org/english/news/malaysian/mahathir-meeting09152016203927.html

Yatim, R. (1995). Freedom under executive power in Malaysia: A study of executive supremacy. Kuala Lumpur: Endowment. 